\title{
Inherited Variants in $B L M$ and the Risk and Clinical Characteristics of Breast Cancer
}

\author{
Wojciech Kluźniak ${ }^{1}$, Dominika Wokołorczyk ${ }^{1}$, Bogna Rusak ${ }^{1}$, Tomasz Huzarski 1,2, \\ Aniruddh Kashyap ${ }^{1}$, Klaudia Stempa 1D, Helena Rudnicka ${ }^{1}$, Anna Jakubowska 1,3 ${ }^{1}$, \\ Marek Szwiec ${ }^{4}$, Sylwia Morawska ${ }^{1}$, Katarzyna Gliniewicz ${ }^{1}$, Karina Mordak ${ }^{1}$, \\ Małgorzata Stawicka ${ }^{2}$, Joanna Jarkiewicz-Tretyn ${ }^{5}$, Magdalena Cechowska ${ }^{5}$, Paweł Domagała ${ }^{6}$, \\ Tadeusz Dębniak ${ }^{1}$, Marcin Lener ${ }^{1}$, Jacek Gronwald ${ }^{1}$, Jan Lubiński ${ }^{1}$, Steven A. Narod ${ }^{7,8}$, \\ Mohammad R. Akbari ${ }^{7,8}$, Cezary Cybulski ${ }^{1, *}$ if \\ and the Polish Hereditary Breast Cancer Consortium ${ }^{\dagger}$ \\ 1 International Hereditary Cancer Center, Department of Genetics and Pathology, \\ Pomeranian Medical University in Szczecin, 71-252 Szczecin, Poland; kluzniak.w@gmail.com (W.K.); \\ dominikawok@o2.pl (D.W.); b_rusak@yahoo.com (B.R.); huzarski@pum.edu.pl (T.H.); \\ kashyap@pum.edu.pl (A.K.); kastempa@gmail.com (K.S.); helena.rudnicka@pum.edu.pl (H.R.); \\ aniaj@pum.edu.pl (A.J.); sylmoraw@gmail.com (S.M.); katarzynagliniewicz@gmail.com (K.G.); \\ Karina_m@wp.pl (K.M.); debniak@sci.pum.edu.pl (T.D.); marcinlener@poczta.onet.pl (M.L.); \\ jgron@pum.edu.pl (J.G.); lubinski@pum.edu.pl (J.L.) \\ 2 Department of Clinical Genetics and Pathology, University of Zielona Góra, 65-046 Zielona Góra, Poland; \\ gosiastawicka@wp.pl \\ 3 Independent Laboratory of Molecular Biology and Genetic Diagnostics, Pomeranian Medical University in \\ Szczecin, 71-252 Szczecin, Poland \\ 4 Department of Surgery and Oncology, University of Zielona Góra, 65-046 Zielona Góra, Poland; \\ szwiec72@gmail.com \\ 5 Cancer Genetics Laboratory, 87-100 Toruń, Poland; jarkiewicztretyn@poczta.onet.pl (J.J.-T.); \\ mcechowska@gmail.com (M.C.) \\ 6 Department of Pathology, Pomeranian Medical University in Szczecin, 71-252 Szczecin, Poland; \\ paweldom@hotmail.com \\ 7 Women's College Research Institute, Women's College Hospital, Toronto, M5S 1B2 ON, Canada; \\ Steven.Narod@wchospital.ca (S.A.N.); mohammad.akbari@utoronto.ca (M.R.A.) \\ 8 Dalla Lana School of Public Health, University of Toronto, Toronto, M5T 3M7 ON, Canada \\ * Correspondence: cezarycy@pum.edu.pl \\ + Details see Appendix A.
}

Received: 27 August 2019; Accepted: 10 October 2019; Published: 13 October 2019

\begin{abstract}
Bloom Syndrome is a rare recessive disease which includes a susceptibility to various cancers. It is caused by homozygous mutations of the BLM gene. To investigate whether heterozygous carriers of a BLM mutation are predisposed to breast cancer, we sequenced BLM in 617 patients from Polish families with a strong family history of breast cancer. We detected a founder mutation (c.1642C>T, p.Gln548Ter) in 3 of the 617 breast cancer patients $(0.49 \%)$ who were sequenced. Then, we genotyped 14,804 unselected breast cancer cases and 4698 cancer-free women for the founder mutation. It was identified in 82 of 14,804 (0.55\%) unselected cases and in 26 of $4698(0.55 \%)$ controls $(\mathrm{OR}=1.0 ; 95 \% \mathrm{CI} 0.6-1.6)$. Clinical characteristics of breast cancers in the BLM mutation carriers and non-carriers were similar. Loss of the wild-type BLM allele was not detected in cancers from the BLM mutation carriers. No cancer type was more common in the relatives of mutation carriers compared to relatives of non-carriers. The BLM founder mutation p.Gln548Ter, which in a homozygous state is a cause of Bloom syndrome, does not appear to predispose to breast cancer in a heterozygous state. The finding casts doubt on the designation of $B L M$ as an autosomal dominant breast cancer susceptibility gene.
\end{abstract}


Keywords: BLM; mutation; cancer; breast cancer; risk; hereditary; survival

\section{Introduction}

Homozygous mutations of the BLM gene are the cause of a rare recessive genetic disorder, Bloom syndrome, which is characterized by chromosomal instability, immunodeficiency, and a predisposition to different malignancies, including breast cancer [1]. The disease is most common in the Ashkenazi Jewish population but is represented (less frequently) in several Eastern European countries as well [2].

Human BLM protein belongs to the RecQ helicase family [3]. BLM plays many different functions in maintenance of genomic integrity [4]. For example, it is required for fork stability during unperturbed DNA replication. It stabilizes forks challenged by DNA damage or other agents that cause polymerase stalling and assists in replication restart [5]. BLM also plays an important role in homologous recombination DNA repair [6]. It senses DNA damage and recruits other repair proteins to the site of DNA breaks after irradiation in an ATM-dependent manner [7]. BLM is part of the BRCA1 multi-subunit protein complex, referred to as the BRCA1-genome surveillance complex, which includes other DNA damage repair proteins such as MSH2-MSH6 and MLH1, as well as ATM, NBS1, and MRE11 [8]. BLM has been implicated in the Fanconi anemia pathway through interaction with RAD51, RAD51D, and FANCJ [9]. Cells homozygous for a BLM mutation (from patients with Bloom syndrome) exhibit chromosomal instability characterized by a high rate of sister chromatid exchanges and vast structural rearrangements [10]. It is therefore not surprising that cancer is the most frequent complication in individuals with Bloom syndrome. Patients with Bloom syndrome are at high risk of a wide variety of cancer types. The distribution of cancers in individuals with Bloom syndrome is similar to that seen in the general population, but they occur at young age and multiple primary cancers are more common. There is clear evidence that BLM mutations in a homozygous state predispose to early onset breast cancer with a mean age of diagnosis of about 33 years [11]. Therefore, we reasoned that BLM is a good candidate for an autosomal dominant breast cancer susceptibility gene.

It is not clear if heterozygous carriers of BLM mutations are at increased cancer risk, and if so, whether BLM should be included in cancer test panels for clinical use. There are several association studies with inconsistent results. In the first study, Sokolenko et al. detected the c.1642C $>$ T (p.Gln548Ter) mutation of BLM in 17 of 1498 Russian breast cancer cases and 2 of 1093 controls (OR $=6.3, p=0.01$ ) [12]. In the second study, Prokofyeva et al. reported the same mutation in 15 of 3188 cases and 2 of 2458 controls from Russia and Belarus (OR $=5.1, p=0.03)$ [13]. In a later study, the p.Gln548Ter mutation was detected with equal frequency $(0.4 \%)$ in breast cancer cases (6 of 1400) and in population controls from Russia (35 of 7920) (OR = 0.97, 95\%CI 0.37-2.41, $p=0.9$ ) [14].

The BLM p.Gln548Ter mutation is the most common cause of Bloom syndrome in Slavic individuals, including Poland and Russia [15]. Among Jews, the predominant mutation, referred to as BLMAsh is a 6-bp deletion and 7-bp insertion at nucleotide position 2207 of the BLM gene [2]. Two association studies of this mutation in Jewish women, by Gruber et al. and by Cleary et al., reported elevated but non-significant odds ratios of $1.8(95 \% \mathrm{CI} 0.6-4.9)$ and $1.6(95 \% \mathrm{CI} 0.5-5.4)$ respectively, for breast cancer, given the BLMAsh founder mutation $[16,17]$. In a cross-sectional study, no cancer type was found to be overrepresented among 326 relatives of BLMAsh mutation carriers, compared to 503 family members of controls [18]. In a prospective study of 152 women with the BLMAsh mutation, no cancer site was seen more often than expected (mean follow-up 10 years) [19]. In summary, the epidemiology evidence from Eastern Europe favored the hypothesis that BLM mutations play a role in breast cancer predisposition, but other studies have led us to question this hypothesis.

To investigate whether or not the presence of a BLM mutation increases breast cancer risk, we studied approximately 15,000 women with breast cancer and 5000 controls from Poland. Further, we compared the clinical characteristics of breast cancers in carriers of a BLM mutation with cancers in 
non-carriers. We reviewed the pedigrees of women who have breast cancer and carry a BLM mutation and compared these with the pedigrees of breast cancer cases without a mutation. We analyzed loss of heterozygosity $(\mathrm{LOH})$ at the BLM locus in breast cancer tissues from six women who carried a $B L M$ truncating mutation.

\section{Results}

We identified a truncating mutation of the BLM gene in three of 617 women with hereditary breast cancer who underwent full gene sequencing. All three had the same mutation c.1642 C>T (p.Gln548Ter). This mutation in its homozygous state is the cause of Bloom syndrome [15,20].

In the second step, the c.1642 C>T (p.Gln548Ter) allele was genotyped in 14,804 patients with unselected breast cancer and 4698 controls. It was detected in $82(0.55 \%)$ unselected cases and in 26 $(0.55 \%)$ controls $(\mathrm{OR}=1.0,95 \% \mathrm{CI} 0.6-1.6, p=1.0)$. The mutation frequency in 2245 women with familial breast cancer (from unselected cases) was $0.49 \%(\mathrm{OR}=0.9,95 \% \mathrm{CI} 0.4-1.8, p=0.9)$. The mutation frequency was $0.60 \%$ for women diagnosed at age of 50 years or below and was $0.50 \%$ for those diagnosed above the age of 50 years (Table 1 ).

Table 1. Prevalence of BLM p.Gln548Ter founder mutation in 14,804 women with breast cancer, by age and family history and in 4,698 cancer-free women.

\begin{tabular}{|c|c|c|c|c|c|}
\hline Group & Total $(n)$ & $\begin{array}{l}\text { BLM p.Gln548Ter } \\
\text { Mutation Positive }\end{array}$ & Prevalence (\%) & OR (CI 95\%) & $p$-Value \\
\hline \multicolumn{6}{|c|}{ Patients with Breast Cancer } \\
\hline All cases & 14,804 & 82 & $0.55 \%$ & $1.0(0.6-1.6)$ & 1.0 \\
\hline \multicolumn{6}{|c|}{ Age (years) } \\
\hline$\leq 40$ & 1791 & 14 & $0.78 \%$ & $1.4(0.7-2.7)$ & 0.4 \\
\hline $41-50$ & 6145 & 34 & $0.55 \%$ & $1.0(0.6-1.7)$ & 1.0 \\
\hline $51-60$ & 3289 & 16 & $0.49 \%$ & $0.9(0.5-1.6)$ & 0.8 \\
\hline $61-70$ & 2247 & 12 & $0.53 \%$ & $1.0(0.5-1.9)$ & 0.9 \\
\hline$\geq 71$ & 1332 & 6 & $0.45 \%$ & $0.8(0.3-2.0)$ & 0.8 \\
\hline \multicolumn{6}{|c|}{ Number of Relatives with Breast Cancer* } \\
\hline 0 & 11,387 & 64 & $0.56 \%$ & $1.0(0.6-1,6)$ & 0.9 \\
\hline 1 & 1719 & 8 & $0.47 \%$ & $0.8(0.4-1.9)$ & 0.8 \\
\hline$\geq 2$ & 526 & 3 & $0.57 \%$ & $1.0(0.3-3.4)$ & 1.0 \\
\hline \multicolumn{6}{|c|}{ Reference } \\
\hline Cancer-free controls & 4698 & 26 & $0.55 \%$ & - & - \\
\hline
\end{tabular}

The clinical characteristics of the patients with breast cancer with and without a BLM mutation is shown in Table 2. Carriers and non-carriers were similar in regards to age of diagnosis, histology, tumor size, lymph-node status and ER, PR, HER2 status. Bilateral tumors were similarly frequent in both groups $(6.3 \%$ versus $4.7 \%$; $p=0.7)$. 
Table 2. Clinical characteristics of breast cancers in carriers of the BLM p.Gln548Ter mutation and non-carriers.

\begin{tabular}{|c|c|c|c|}
\hline Characteristic & $\begin{array}{c}\text { BLM p.Gln548Ter } \\
\text { Positive } \\
\text { Cases } \\
n=82\end{array}$ & $\begin{array}{c}\text { BLM p.Gln548Ter } \\
\text { Negative } \\
\text { Cases } \\
n=14,722\end{array}$ & $p$-Value \\
\hline Age at diagnosis (years) & $52.8(29-79)$ & $53.7(18-93)$ & 0.5 \\
\hline \multicolumn{4}{|l|}{ Histological features } \\
\hline Ductal, grade 3 & $11 / 59(18.6 \%)$ & $2409 / 11,560(20.8 \%)$ & 0.8 \\
\hline Ductal, grade 1-2 & $25 / 59(42.4 \%)$ & $4724 / 11,560(40.1 \%)$ & 1.0 \\
\hline Ductal, grade unknown & $7 / 59(11.9 \%)$ & $858 / 11,560(7.4 \%)$ & 0.3 \\
\hline Medullary & $4 / 59(6.8 \%)$ & $393 / 11,560(3.4 \%)$ & 0.3 \\
\hline Lobular & $7 / 59(11.9 \%)$ & $1502 / 11,560(13.0 \%)$ & 0.9 \\
\hline Tubulolobular & $0 / 59(0 \%)$ & $156 / 11,560(1.3 \%)$ & 0.7 \\
\hline DCIS with microinvasion & $0 / 59(0 \%)$ & $410 / 11,560(3.5 \%)$ & 0.3 \\
\hline Other or undefined & $5 / 59(8.5 \%)$ & $1108 / 11,560(9.6 \%)$ & 0.9 \\
\hline \multicolumn{4}{|l|}{ Receptor status } \\
\hline Oestrogen receptor-positive & $34 / 52(65.4 \%)$ & $7004 / 10,372(67.5 \%)$ & 0.9 \\
\hline Progesterone receptor-positive & $35 / 49(71.4 \%)$ & $6959 / 9891(70.4 \%)$ & 1.0 \\
\hline HER2-positive & $9 / 42(21.4 \%)$ & $1520 / 8392(18.1 \%)$ & 0.7 \\
\hline Triple-negative & $9 / 42(21.4 \%)$ & 1387/8004 (17.3\%) & 0.6 \\
\hline \multicolumn{4}{|l|}{ Size $(\mathrm{cm})$} \\
\hline$<1$ & $3 / 47(6.4 \%)$ & $1041 / 9621(10.8 \%)$ & 0.5 \\
\hline $1-1,9$ & $20 / 47(42.6 \%)$ & $3882 / 9621(40.3 \%)$ & 0.9 \\
\hline $2-4,9$ & $22 / 47(46.8 \%)$ & $4272 / 9621(44.4 \%)$ & 0.9 \\
\hline$\geq 5$ & $2 / 47(4.3 \%)$ & $426 / 9621(4.4 \%)$ & 1.0 \\
\hline Lymph node-positive & $25 / 51(49.0 \%)$ & $4423 / 9883(44.8 \%)$ & 0.6 \\
\hline Bilateral & $4 / 63(6.3 \%)$ & $563 / 11,984(4.7 \%)$ & 0.7 \\
\hline Chemotherapy (yes) & $41 / 63(65.1 \%)$ & $6499 / 10,680(60.9 \%)$ & 0.6 \\
\hline Tamoxifen (yes) & $26 / 42(61.9 \%)$ & $5228 / 7969(65.6 \%)$ & 0.7 \\
\hline Vital status (deceased) & $15 / 81(18.5 \%)$ & $2369 / 13,640(17.4 \%)$ & 0.9 \\
\hline
\end{tabular}

Footnote: Data are mean (range) or number/total (\%), $p$-value compares mutation-positive with mutation-negative patients and was calculated with Fisher's exact test, DCIS = ductal carcinoma in situ.

Survival data were available for 13,721 women with breast cancer. The mean follow-up time was 64 months. There were 15 deaths recorded in 81 BLM mutation carriers (18.5\%) compared with 2368 deaths in 13,640 non-carriers (17.4\%) ( $\mathrm{HR}=1.01,95 \% \mathrm{CI} 0.6-1.7, p=0.98$; log rank test). The 10-year survival was $76 \%$ for the carriers compared to $77 \%$ for non-carriers. After adjusting for age of diagnosis, the HR for mortality associated with the BLM mutation was 0.99 (95\%CI 0.6-1.6; $p=0.97$; Cox regression analysis).

We reviewed the pedigrees of women who carry the BLM mutation to see if there might be an excess of cancers at any site in first- or second-degree relatives. There were 63 cancers in 75 families with a BLM mutation (84\%) versus 11,511 cancers in 13,556 BLM mutation negative families $(85 \%)$ (Table 3). No particular cancer type was more common in the relatives of mutation carriers compared to relatives of non-carriers. 
Table 3. Cancers reported in the families of the 75 unselected breast cancer cases of a BLM mutation compared to those reported by the 13,557 non-carrier cases.

\begin{tabular}{|c|c|c|c|c|c|}
\hline \multirow[t]{2}{*}{ Cancer Site } & \multicolumn{2}{|c|}{$\begin{array}{c}\text { Number }(\%) \text { of Cancers in } \\
\text { Relatives of } B L M \\
\text { p.Gln548Ter Positive Women } \\
\text { ( } n=75 \text { families) }\end{array}$} & \multicolumn{2}{|c|}{$\begin{array}{l}\text { Number }(\%) \text { of Cancers in } \\
\text { Relatives of } B L M \text { p.Gln } 548 \text { Ter } \\
\text { Negative Women } \\
(n=13,557 \text { families })\end{array}$} & \multirow[t]{2}{*}{$p$-Value } \\
\hline & $n$ & $\%$ & $n$ & $\%$ & \\
\hline Breast & 11 & $14.7 \%$ & 2234 & $16.5 \%$ & 0.8 \\
\hline Colon & 6 & $8.0 \%$ & 1041 & $7.7 \%$ & 0.9 \\
\hline Kidney & 3 & $4.0 \%$ & 376 & $2.8 \%$ & 0.8 \\
\hline Larynx & 0 & $0.0 \%$ & 525 & $3.9 \%$ & 0.2 \\
\hline Lung & 14 & $18.7 \%$ & 2007 & $14.8 \%$ & 0.4 \\
\hline Leukemia or Lymphoma & 3 & $4.0 \%$ & 525 & $3.9 \%$ & 0.9 \\
\hline Pancreas & 2 & $2.7 \%$ & 390 & $2.9 \%$ & 0.9 \\
\hline Prostate & 6 & $8.0 \%$ & 909 & $6.7 \%$ & 0.8 \\
\hline Stomach & 6 & $8.0 \%$ & 1161 & $8.6 \%$ & 0.9 \\
\hline Cervix or Endometrium & 9 & $12.0 \%$ & 1408 & $10.4 \%$ & 0.8 \\
\hline Ovary & 3 & $4.0 \%$ & 479 & $3.5 \%$ & 0.8 \\
\hline All cancers & 63 & $84.0 \%$ & 11,511 & $84.9 \%$ & 0.9 \\
\hline
\end{tabular}

Footnote: family history in first- and second-degree relatives was available for 75 of 82 (91\%) BLM mutation carriers and 13,557 of $14,722(92 \%)$ non-carriers.

We analyzed tumor DNA of six women with a BLM mutation for loss of heterozygosity. The wild-type BLM allele was retained in all cases (Figure 1).
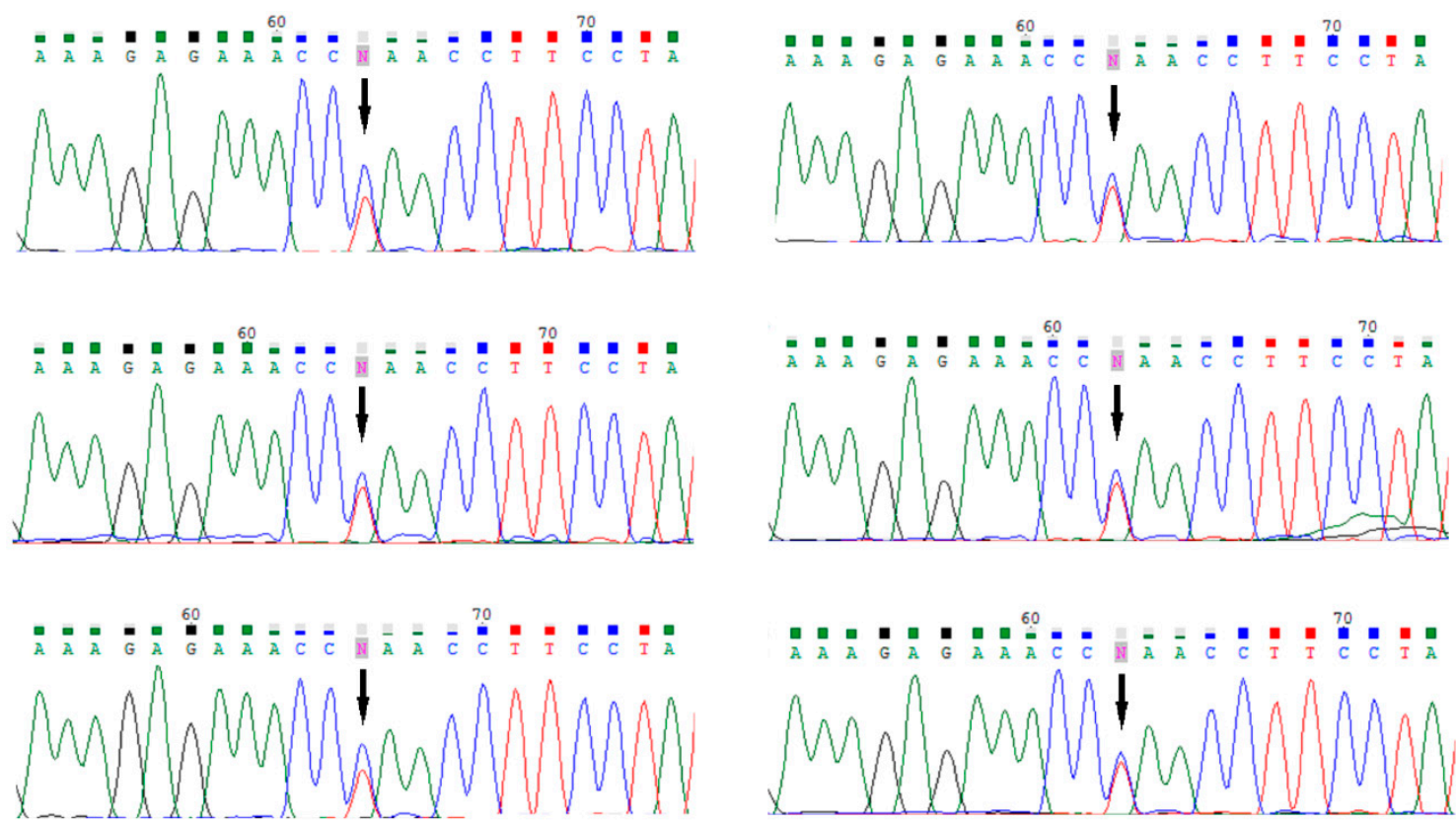

Figure 1. Loss of heterozygosity $(\mathrm{LOH})$ analysis in breast cancer tissues from six carriers of $B L M$ mutation; retention of the wild type $B L M$ allele in breast cancer seen in six tested tumor samples. The p.Gln548Ter BLM mutation is indicated by arrow $(\downarrow)$. 


\section{Discussion}

This is the largest study to date to evaluate the association between (heterozygous) mutations in the $B L M$ gene and breast cancer. We approached the question in several ways, including a case-control study (association study) and a pedigree analysis. We also asked if cancers with and without BLM mutations showed differences in their clinical presentation and survival. Finally, we sought loss of heterozygosity at the BLM locus in tumor tissues (given that $\mathrm{LOH}$ is a signature event in most cancer syndromes with homologous repair deficiency). In none of these separate evaluations was there evidence of cancer predisposition for carriers of a BLM pathogenic mutation.

We identified one recurrent truncating mutation of $B L M$ (c.1642 C>T, p.Gln548Ter). This mutation is a cause of Bloom syndrome, as we and others diagnosed patients with Bloom syndrome homozygous for this protein-truncating variant of $B L M[15,20]$. However, this specific mutation appears to not be associated with an increased risk of breast cancer among Polish women. Our results contrast with the results of Sokolenko et al. and of Prokofyeva, et al., who reported separately that carriers of c.1642 C > T (p.Gln548Ter) founder mutation are at about a 6-fold increased risk of breast cancer [12,13]. Other studies showed no significant association and are in line with our negative study [14,16-20]. Our study is large and benefits from genetic homogeneity of Poland, which is populated by ethnic Slavs. The country is well-suited for association studies because the genetic similarity between cases and controls is assured, and spurious results due to admixture have not been reported. Patients with breast cancer were not selected for family history.

There are several possible reasons for discrepancy between the results of our study and those of Sokolenko, et al., and of Prokofyeva, et al. It is possible that the differences are due to chance. It is not surprising that the first paper reported a positive association because of the tendency to submit positive results by authors and to accept positive results by journals. This is why it is essential that these studies be replicated prior to clinical implementation. It is not possible that differences between countries were due to different mutations as the same Slavic BLM founder mutation was studied. In our study we identified 108 carriers of the mutation in total, compared to a total of 36 for the first two positive studies combined. All subsequent studies have been negative [14,16-20]. Based on our study and the studies published to date, there is insufficient evidence that BLM is an autosomal dominant breast cancer susceptibility gene.

The DNA damage signaling pathway plays a crucial role in the maintenance of the integrity of the genome in response to DNA damage and has been implicated in the pathogenesis of cancer. The gene from Bloom syndrome acts in the DNA damage repair signaling pathway [8]. It is interesting that heterozygous mutations in other genes in this pathway (i.e., BRCA1, BRCA2, CHEK2, NBN, ATM) predispose to breast cancer, but a heterozygous mutation in $B L M$ does not appear to be pathogenic for breast cancer.

$B R C A 1, B R C A 2$ and NBN act as classical tumor suppressor genes. Both alleles of these tumor suppressor genes are inactivated before tumor formation [21]. $\mathrm{LOH}$ is observed in most cancers in $B R C A 1, B R C A 2$, and NBN carriers [22,23]. However, for some genes and cancer types, loss or mutation of a single allele may be sufficient to promote tumorigenesis. This phenomenon may be caused by a gene-dosage effect (haploinsufficiency) or the inactivating property the mutant protein may have on a particular pathway (dominant-negative effect) [24]. For example, it has been shown that the mechanism of tumorigenesis in association with CHEK2 variants does not involve $\mathrm{LOH}$. It is proposed that the mechanism by which some CHEK2 mutants may contribute to tumorigenesis is haploinsufficiency, i.e., due to lower level of expression [25-27]. Similarly, tumors that develop in heterozygous carriers of ATM missense mutations appear to be the consequence of a dominant-negative effect of the ATM protein [28,29]. As expected from the dominant-negative model, only mutations that do not lead to the absence of protein appear to be pathogenic (i.e., missense mutations or in-frame deletions). Some missense mutations in CHEK2 may also have a dominant-negative effect. For example, CHEK2 I157T protein is stable and it dimerizes with the wild-type CHEK2 co-expressed in human cells. 
This variant may have negative effect on the pool of normal CHEK2 protein in heterozygous carrier cells by formation of heterodimers with wild-type CHEK2 [30].

Our robust analysis suggests that carriers of a heterozygous mutation in BLM are not at elevated risk of breast cancer. It has been reported that tumors in BLM mutation carriers do not demonstrate $\mathrm{LOH}$, and normal BLM protein is expressed in tumor cells $[16,22,31]$. In our study, LOH analysis at the BLM locus was performed in DNA isolated from breast cancers from six BLM (p.Gln548Ter) mutation-positive women. The wild-type BLM allele was retained in all cases. It is therefore possible that loss of function of a single BLM allele (i.e., haploinsufficiency) is not sufficient to promote carcinogenesis in the breast.

\section{Material and methods}

\subsection{Hereditary Breast Cancer Cases}

For the first step, we selected 617 unrelated breast cancer patients from 617 Polish families with a family history of breast cancer. We included women with a strong family history for breast cancer (in first- and second-degree relatives). Among the 617 probands with breast cancer, there were 160 women from families with at least four women affected with breast cancer, 378 women from families with three affected, and 79 women from families with two affected (at least one had bilateral breast cancer or breast cancer below age 50). The mean number of breast cancers per family was 3.4. Among the 617 probands with breast cancer, 104 women were diagnosed at age 40 years or below, 226 women were diagnosed at age 41 to 50 years, 200 women were diagnosed at age 51 to 60 years, and 87 women were diagnosed above age of 60 years. The mean age of breast cancer diagnosis among the 617 probands was 46 years (range 28 to 76 years). Of the 617 patients, 81 reported a family history of ovarian cancer and 16 reported a family history of male breast cancer. The 617 probands were selected from a registry of 3,519 familial breast cancer cases housed at the Hereditary Cancer Center in Szczecin based on the number and age of onset of breast cancer cases among their relatives, and based on that they tested negative for a panel of 17 founder Polish mutations of BRCA1, BRCA2, CHEK2, PALB2, $N B N$, and RECQL [32]. All probands were ethnic Poles.

\subsection{Unselected Cases of Breast Cancer}

We studied 14,804 prospectively ascertained cases of invasive breast cancer, diagnosed from 1996 to 2012, at 18 different hospitals in Poland (mean age of diagnosis 54 years, range 18-93). All women who were diagnosed with a first primary invasive breast cancer at the participating centers were eligible. Patients with purely intraductal or intralobular cancer were excluded (DCIS or LCIS) but patients with DCIS with micro-invasion were included. Patients were unselected for family history. The patient participation rate among invited women was $76.1 \%$. Information was recorded on clinical characteristics of breast cancers through review of medical records. Family history included the number of first- and second-degree relatives with any cancer. Of the 14,804 unselected cases, 2245 patients $(16 \%)$ reported at least one first- or second-degree relative with breast cancer (familial breast cancer cases from unselected series). The definition of a familial case (from unselected cases) was the presence of one or more breast cancers in first or second degree relatives of a womanwith unselected breast cancer (i.e., two or more breast cancers in first or second degree relatives in a family). Survival data were obtained (status: alive or dead, the date of death) from Polish Ministry of the Interior and Administration in July 2014. The Ethics Committee of Pomeranian Medical University in Szczecin approved the study (IRB No. KB-0012/97/17).

\subsection{Controls}

The purpose of the control group was to estimate the BLM mutation frequency in the underlying Polish population. The control group included 4,698 Polish cancer-free women age 18 to 94 years (mean age, 53.0 years) derived from four sources. The first consisted of 987 women from the region 
of Szczecin (age range, 24 to 84 years) who were part of a population-based study of the 1.5 million residents of West Pomerania (North-West Poland) designed to identify familial aggregations of cancer and were interviewed in 2007. The second series consisted of 1717 unselected women (age range 32-72) who participated in mammography screening at 8 different centers all over Poland between 2009 and 2011 (Kielce, Legnica, Olsztyn, Poznań, Szczecin, Świdnica, Toruń, and Zielona Góra) and provided a blood sample for DNA analysis. The third control group included 1036 women (age range, 20-94 years) selected at random from the computerized patient lists of family practices located in the region of Opole (South Poland). These women were invited to participate by mail and participated in 2012 and 2013. The fourth series included 958 Polish women (age range 50-66 years), who participated in a colonoscopy screening program for colorectal cancer between 2007 and 2010 in Szczecin, Białystok and Lódź [33].

\subsection{Sequencing of the BLM Gene}

We analyzed the entire coding sequence of BLM from the exome sequencing data of 617 women with hereditary breast cancer (step 1) as described previously [33]. The Agilent SureSelect human exome kit (V6) was used for capturing target regions. The regions were sequenced on Illumina NextSeq 500. The mean depth of coverage was approximately 100, $97.4 \%$ of the CCDS exons were covered at $20 \times$ depth of coverage and higher, which was used for variant calling. We looked for protein truncating genetic variants, including frame shift insertions, deletions, stop codon mutations, and variants at the consensus splice sites, which are likely to be dysfunctional.

\subsection{Genotyping}

We genotyped 14,804 women with breast cancer and 4,698 controls for the BLM mutation, which was detected by sequencing (step 2). DNA was isolated from 5 to $10 \mathrm{~mL}$ of peripheral blood. The c.1642C $>\mathrm{T}$ (p.GIn548Ter) mutation was genotyped using a TaqMan assay (Thermo Fisher Scientific, Waltham, MA, USA) in a LightCycler Real-Time PCR 480 System (Roche Life Science, Mannheim, Germany). All mutations were confirmed by Sanger sequencing. Sequencing reactions were performed using a BigDye Terminator v3.1 Cycle Sequencing Kit (Thermo Fisher Scientific) according to the manufacturer's protocol. Sequencing products were analyzed on the ABI prism 3100 Genetic Analyzer (Thermo Fisher Scientific).

\subsection{Loss of Heterozygosity Analysis}

Formalin-fixed paraffin-embedded (FFPE) tissue samples from eight BLM mutation carriers were available in the Department of Pathology of Pomeranian Medical University in Szczecin. A pathology review of these samples was conducted by a pathologist associated with the study. Tissue samples of good quality were available from six patients. Loss of heterozygosity $(\mathrm{LOH})$ analysis at the BLM locus was performed in DNA from micro-dissected tumors from six BLM mutation-positive women (p.Gln548Ter) using methodology described previously [34] with minor modifications: (1) DNA was isolated with QIAamp DNA FFPE Tissue Kit (from QIAGEN); (2) LOH was analyzed by direct Sanger sequencing of a $155 \mathrm{bp}$ DNA fragment containing the p.Gln548Ter mutation (forward primer $5^{\prime}$ ctcttatttcccaggaaatgttctc; reverse primer $5^{\prime}$ cttcccagtcatcatcatcatc).

\subsection{Statistical Analysis}

The prevalence of the BLM allele p.Gln548Ter was estimated in 14,804 breast cancer cases and 4,698 cancer-free women. Odds ratios were generated from two-by-two tables. Women with breast cancer, with and without a BLM mutation, were compared for age at diagnosis and clinical features of the breast cancers. Statistical significance was assessed using Fisher exact test or Chi-squared test where appropriate. Means were compared using t-test.

To estimate the survival of women with and without the mutation, we followed the breast cancer patients from the date of diagnosis until the date of death or July 2014. We compared the survival 
between mutation carriers and non-carriers by log-rank test. An age-adjusted hazard ratio was calculated using Cox regression analysis.

\section{Conclusions}

Our study and the studies published to date do not support the hypothesis that BLM mutations, in a heterozygous state, confer elevated risk of breast cancer (and probably of other cancers). We conclude that the BLM gene should not be included in cancer test panels for clinical use. Women with heterozygous BLM mutations should not be advised that they are at increased risk of breast cancer, and should not be counseled to intensify surveillance.

Author Contributions: W.K. designed the study, analysed study data and drafted the manuscript. D.W., B.R., K.S., H.R., S.M., K.G. selected and prepared DNA samples for sequencing and genotyping and performed genotyping. T.H., M.S. (Marek Szwiec), K.M., M.S. (Małgorzata Stawicka), J.J.-T., M.C., T.D., J.G., C.C. enrolled patients and controls for the study, and collected phenotypic data for the study. A.K. performed statistical analyses. W.K., A.J., M.L. contributed to Sanger sequencing validation, designed and performed LOH study. P.D. selected, prepared and provided tissue samples for LOH analysis. M.R.A. performed bioinformatics analysis of exome sequencing data and assisted with drafting the manuscript. S.A.N. and J.L. assisted in coordination of the study and in drafting the manuscript. C.C. conceived, designed and coordinated the study and assisted with drafting the manuscript. All authors read and approved the final manuscript.

Funding: This research was funded by National Science Centre, Poland; project number: 2015/17/B/NZ5/02543.

Acknowledgments: This study was funded by National Science Centre, Poland; project number: 2015/17/B/NZ5/02543. The study was approved by the Ethics Committee of the Pomeranian Medical University in Szczecin (IRB No. KB-0012/97/17). Patient clinical data have been obtained in a manner conforming with IRB ethical guidelines. Informed consent was obtained from all individual participants included in the study. We thank Daria Zanoza, Ewa Putresza for their help with managing databases.

Conflicts of Interest: The authors declare no conflict of interests.

\section{Appendix A}

Other members of Polish Hereditary Breast Cancer Consortium are: M. Bębenek, D. Godlewski, S. Gozdecka-Grodecka, S. Goźdź, O. Haus, H. Janiszewska, M. Jasiówka, E. Kilar, R. Kordek, B. Kozak-Klonowska, G. Książkiewicz, A. Mackiewicz, E. Marczak, J. Mituś, Z. Morawiec, S. Niepsuj, R. Sibilski, M. Siołek, J. Sir, D. Surdyka, A. Synowiec, C. Szczylik, R. Uciński, B. Waśko, R. Wiśniowski, T. Byrski, B. Górski.

\section{References}

1. Ellis, N.A.; Groden, J.; Ye, T.Z.; Straughen, J.; Lennon, D.J.; Ciocci, S.; Proytcheva, M.; German, J. The Bloom's syndrome gene product is homologous to RecQ helicases. Cell 1995, 83, 655-666. [CrossRef]

2. Fares, F.; Badarneh, K.; Abosaleh, M.; Harari-Shaham, A.; Diukman, R.; David, M. Carrier frequency of autosomal-recessive disorders in the Ashkenazi Jewish population: Should the rationale for mutation choice for screening be reevaluated? Prenat. Diagn. 2008, 28, 236-241. [CrossRef] [PubMed]

3. Chu, W.K.; Hickson, I.D. RecQ helicases: Multifunctional genome caretakers. Nat. Rev. Cancer 2009, 9, 644-654. [CrossRef] [PubMed]

4. Tikoo, S.; Sengupta, S. Time to bloom. Genome Integr. 2010, 1, 14. [CrossRef] [PubMed]

5. Ralf, C.; Hickson, I.D.; Wu, L. The Bloom's syndrome helicase can promote the regression of a model replication fork. J. Biol. Chem. 2006, 281, 22839-22846. [CrossRef] [PubMed]

6. Wu, L.; Hickson, I.D. The Bloom's syndrome helicase suppresses crossing over during homologous recombination. Nature 2003, 426, 870-874. [CrossRef] [PubMed]

7. Bischof, O.; Kim, S.H.; Irving, J.; Beresten, S.; Ellis, N.A.; Campisi, J. Regulation and localization of the Bloom syndrome protein in response to DNA damage. J. Cell Biol. 2001, 153, 367-380. [CrossRef] [PubMed]

8. Futaki, M.; Liu, J.M. Chromosomal breakage syndromes and the BRCA1 genome surveillance complex. Trends Mol. Med. 2001, 7, 560-565. [CrossRef]

9. Suhasini, A.N.; Brosh, R.M. Fanconi anemia and Bloom's syndrome crosstalk through FANCJ-BLM helicase interaction. Trends Genet. 2012, 28, 7-13. [CrossRef] 
10. GERMAN, J.; ARCHIBALD, R.; BLOOM, D. CHROMOSOMAL BREAKAGE IN A RARE AND PROBABLY GENETICALLY DETERMINED SYNDROME OF MAN. Science 1965, 148, 506-507. [CrossRef]

11. Cunniff, C.; Djavid, A.R.; Carrubba, S.; Cohen, B.; Ellis, N.A.; Levy, C.F.; Jeong, S.; Lederman, H.M.; Vogiatzi, M.; Walsh, M.F.; et al. Health supervision for people with Bloom syndrome. Am. J. Med. Genet. 2018, 176, 1872-1881. [CrossRef] [PubMed]

12. Sokolenko, A.P.; Iyevleva, A.G.; Preobrazhenskaya, E.V.; Mitiushkina, N.V.; Abysheva, S.N.; Suspitsin, E.N.; Kuligina, E.S.h.; Gorodnova, T.V.; Pfeifer, W.; Togo, A.V.; et al. High prevalence and breast cancer predisposing role of the BLM c.1642 C>T (Q548X) mutation in Russia. Int. J. Cancer 2012, 130, 2867-2873. [CrossRef] [PubMed]

13. Prokofyeva, D.; Bogdanova, N.; Dubrowinskaja, N.; Bermisheva, M.; Takhirova, Z.; Antonenkova, N.; Turmanov, N.; Datsyuk, I.; Gantsev, S.; Christiansen, H.; et al. Nonsense mutation p.Q548X in BLM, the gene mutated in Bloom's syndrome, is associated with breast cancer in Slavic populations. Breast Cancer Res. Treat. 2013, 137, 533-539. [CrossRef] [PubMed]

14. Anisimenko, M.S.; Kozyakov, A.E.; Paul, G.A.; Kovalenko, S.P. The frequency of the BLM p.Q548X (c.1642C>T) mutation in breast cancer patients from Russia is no higher than in the general population. Breast Cancer Res. Treat. 2014, 148, 689-690. [CrossRef] [PubMed]

15. Suspitsin, E.N.; Sibgatullina, F.I.; Lyazina, L.V.; Imyanitov, E.N. First Two Cases of Bloom Syndrome in Russia: Lack of Skin Manifestations in a BLM c.1642C>T (p.Q548X) Homozygote as a Likely Cause of Underdiagnosis. Mol. Syndromol. 2017, 8, 103-106. [CrossRef] [PubMed]

16. Gruber, S.B.; Ellis, N.A.; Scott, K.K.; Almog, R.; Kolachana, P.; Bonner, J.D.; Kirchhoff, T.; Tomsho, L.P.; Nafa, K.; Pierce, H.; et al. BLM heterozygosity and the risk of colorectal cancer. Science 2002, 297, 2013. [CrossRef] [PubMed]

17. Cleary, S.P.; Zhang, W.; Di Nicola, N.; Aronson, M.; Aube, J.; Steinman, A.; Haddad, R.; Redston, M.; Gallinger, S.; Narod, S.A. Heterozygosity for the BLM(Ash) mutation and cancer risk. Cancer Res. 2003, 63, 1769-1771.

18. Baris, H.N.; Kedar, I.; Halpern, G.J.; Shohat, T.; Magal, N.; Ludman, M.D.; Shohat, M. Prevalence of breast and colorectal cancer in Ashkenazi Jewish carriers of Fanconi anemia and Bloom syndrome. Isr. Med. Assoc. J. 2007, 9, 847-850.

19. Laitman, Y.; Boker-Keinan, L.; Berkenstadt, M.; Liphsitz, I.; Weissglas-Volkov, D.; Ries-Levavi, L.; Sarouk, I.; Pras, E.; Friedman, E. The risk for developing cancer in Israeli ATM, BLM, and FANCC heterozygous mutation carriers. Cancer Genet. 2016, 209, 70-74. [CrossRef]

20. German, J.; Sanz, M.M.; Ciocci, S.; Ye, T.Z.; Ellis, N.A. Syndrome-causing mutations of the BLM gene in persons in the Bloom's Syndrome Registry. Hum. Mutat. 2007, 28, 743-753. [CrossRef]

21. Knudson, A.G. Mutation and cancer: Statistical study of retinoblastoma. Proc. Natl. Acad. Sci. USA 1971, 68, 820-823. [CrossRef] [PubMed]

22. Tomlinson, I.P.; Roylance, R.; Houlston, R.S. Two hits revisited again. J. Med. Genet. 2001, 38, 81-85. [CrossRef] [PubMed]

23. Górski, B.; Debniak, T.; Masojć, B.; Mierzejewski, M.; Medrek, K.; Cybulski, C.; Jakubowska, A.; Kurzawski, G.; Chosia, M.; Scott, R.; et al. Germline 657del5 mutation in the NBS1 gene in breast cancer patients. Int. J. Cancer 2003, 106, 379-381. [CrossRef]

24. Fodde, R.; Smits, R. Cancer biology. A matter of dosage. Science 2002, 298, 761-763. [CrossRef] [PubMed]

25. Sodha, N.; Bullock, S.; Taylor, R.; Mitchell, G.; Guertl-Lackner, B.; Williams, R.D.; Bevan, S.; Bishop, K.; McGuire, S.; Houlston, R.S.; et al. CHEK2 variants in susceptibility to breast cancer and evidence of retention of the wild type allele in tumours. Br. J. Cancer 2002, 87, 1445-1448. [CrossRef] [PubMed]

26. Oldenburg, R.A.; Kroeze-Jansema, K.; Kraan, J.; Morreau, H.; Klijn, J.G.; Hoogerbrugge, N.; Ligtenberg, M.J.; van Asperen, C.J.; Vasen, H.F.; Meijers, C.; et al. The CHEK2*1100delC variant acts as a breast cancer risk modifier in non-BRCA1/BRCA2 multiple-case families. Cancer Res. 2003, 63, 8153-8157. [PubMed]

27. Sodha, N.; Mantoni, T.S.; Tavtigian, S.V.; Eeles, R.; Garrett, M.D. Rare germ line CHEK2 variants identified in breast cancer families encode proteins that show impaired activation. Cancer Res. 2006, 66, 8966-8970. [CrossRef] [PubMed]

28. Spring, K.; Ahangari, F.; Scott, S.P.; Waring, P.; Purdie, D.M.; Chen, P.C.; Hourigan, K.; Ramsay, J.; McKinnon, P.J.; Swift, M.; et al. Mice heterozygous for mutation in Atm, the gene involved in ataxia-telangiectasia, have heightened susceptibility to cancer. Nat. Genet. 2002, 32, 185-190. [CrossRef] 
29. Scott, S.P.; Bendix, R.; Chen, P.; Clark, R.; Dork, T.; Lavin, M.F. Missense mutations but not allelic variants alter the function of ATM by dominant interference in patients with breast cancer. Proc. Natl. Acad. Sci. USA 2002, 99, 925-930. [CrossRef]

30. Kilpivaara, O.; Vahteristo, P.; Falck, J.; Syrjäkoski, K.; Eerola, H.; Easton, D.; Bartkova, J.; Lukas, J.; Heikkilä, P.; Aittomäki, K.; et al. CHEK2 variant I157T may be associated with increased breast cancer risk. Int. J. Cancer 2004, 111, 543-547. [CrossRef]

31. Maxwell, K.N.; Wubbenhorst, B.; Wenz, B.M.; De Sloover, D.; Pluta, J.; Emery, L.; Barrett, A.; Kraya, A.A.; Anastopoulos, I.N.; Yu, S.; et al. BRCA locus-specific loss of heterozygosity in germline BRCA1 and BRCA2 carriers. Nat. Commun. 2017, 8, 319. [CrossRef] [PubMed]

32. Cybulski, C.; Kluźniak, W.; Huzarski, T.; Wokołorczyk, D.; Kashyap, A.; Rusak, B.; Stempa, K.; Gronwald, J.; Szymiczek, A.; Bagherzadeh, M.; et al. The spectrum of mutations predisposing to familial breast cancer in Poland. Int. J. Cancer 2019. [CrossRef] [PubMed]

33. Cybulski, C.; Kluźniak, W.; Huzarski, T.; Wokołorczyk, D.; Kashyap, A.; Jakubowska, A.; Szwiec, M.; Byrski, T.; Dębniak, T.; Górski, B.; et al. Clinical outcomes in women with breast cancer and a PALB2 mutation: A prospective cohort analysis. Lancet Oncol. 2015, 16, 638-644. [CrossRef]

34. Cybulski, C.; Górski, B.; Debniak, T.; Gliniewicz, B.; Mierzejewski, M.; Masojć, B.; Jakubowska, A.; Matyjasik, J.; Złowocka, E.; Sikorski, A.; et al. NBS1 is a prostate cancer susceptibility gene. Cancer Res. 2004, 64, 1215-1219. [CrossRef] [PubMed]

(C) 2019 by the authors. Licensee MDPI, Basel, Switzerland. This article is an open access article distributed under the terms and conditions of the Creative Commons Attribution (CC BY) license (http://creativecommons.org/licenses/by/4.0/). 